\title{
KAJIAN STRUKTURAL-SEMIOTIK IAN RICHARD NETTON TERHADAP QS. AL-KAHF
}

\author{
Nilna Fadllillah \\ Institut Agama Islam Qomaruddin Bungah Gresik \\ nilna.fa@gmail.com \\ Hasan Mahfudh \\ UIN Sunan Ampel Surabaya \\ hasanmahfudh@uinsby.ac.id
}

\begin{abstract}
The paper describes the structural-semiotic perspective of Ian Richard Netton towards the Qur'anic interpretation of Surah alKahf. The analysis departs from the theory of "surah as a whole". It means that a surah of the Qur'an is a collection of the interconnected units. However, Netton does not provide a thorough interpretation of surah al-Kahf. He only focuses on four stories narrated therein. He argues that the stories in surah al-Kahf contain archetypes and theologemes which lead to the core of this surah that is chaos and harmony. He further stated that every chaos will always be followed by harmony which eventually comes from God's intervention. On the other hand, I also compare Netton's interpretation to the structuralthematic approach initiated by Muhammad al-Ghazāil. In contrast to Netton's interpretation, al-Ghazāi attempts to interpret a sura of the Qur'an in a whole, from beginning to the end. He argues that the essence of surah al-Kahf is to establish monotheistic beliefs. Although they are different in approaches and interpretations, what they did is a prototype of hermeneutical endeavour. Both of them attempt to explore the deepest meaning of a unified surah of the Qur'an.
\end{abstract}

Keywords: Ian Richard Netton, Surah al-Kahf, Structural-Semiotic

Abstrak: Tulisan ini mendeskripsikan perspektif struktural-semiotik Ian Richard Netton terhadap tafsir Alquran QS. al-Kahf. Gagasan interpretasi Netton berangkat dari teori surah as a whole (surah sebagai satu kesatuan keseluruhan), bahwa satu surah Alquran merupakan kumpulan dari unit-unit yang saling berhubungan. Netton tidak menafsirkan surah al-Kahf secara rinci dan menyeluruh, dia hanya fokus membahas empat kisah yang terdapat di dalamnya. Secara keseluruhan, kisah-kisah tersebut memuat archetypes dan theologemes yang menunjukkan bahwa inti dari surah ini adalah chaos and harmony, bahwa di setiap kekacauan, ada harmoni yang berasal dari campur tangan Tuhan. Penulis juga membandingkan pendekatan struktural- 
semiotik Netton dengan pendekatan struktural-tematik yang digagas oleh Muhammad al-Ghazāili. Berbeda dengan Netton, al-Ghazāi mencoba memahami satu surah Alquran secara utuh, dari awal hingga akhir. Dia kemudian menyimpulkan bahwa inti surah al-Kahf adalah mengokohkan keyakinan tauhid. Meski pendekatan dan hasil kedua penafsiran ini berbeda, apa yang dilakukan oleh Netton dan alGhazāi ini dapat disebut sebagai upaya hermeneutis. Keduanya berusaha menggali makna terdalam dari satu kesatuan surah Alquran.

Kata kunci: Ian Richard Netton, surah al-Kahf, struktural-semiotik.

\section{Pendahuluan}

Istilah surah as a unity yang muncul pada akhir abad ke-20 cukup menarik perhatian para pengkaji Alquran, baik dari Timur maupun Barat. Istilah yang dikemukakan oleh Mustansir Mir ini awalnya berangkat dari gagasan mufasir Pakistan, al-Farahịi dan al-Iṣlāhì. Gagasan ini memandang bahwa surah Alquran merupakan satu kesatuan yang bagian atau ayat-ayatnya saling terkait secara koheren. ${ }^{1}$ Namun, di dalam Alquran sendiri terdapat surah-surah yang berisi berbagai tema sehingga kadang secara sekilas tampak tidak saling terkait, salah satunya adalah QS. al-Kahf.

Surah yang terdiri dari 110 ayat ini memuat berbagai tema dan kisah, di antaranya adalah kisah așhāb al-Kahf, kisah pemilik kebun anggur, kisah Nabi Mūsā dan Nabi Hiidhr, serta kisah Dhū al-Qarnayn dan Yajuj wa Majüj. Jika demikian, maka gagasan "surah as a unity" bertentangan dengan kenyataan yang ada di dalam Alquran secara tekstual. Pertentangan ini kemudian coba ditinjau oleh para mufasir, salah satunya dengan menggunakan pendekatan strukturalis. Upaya ini dilakukan oleh seorang pengkaji Islam dari Barat, Ian Richard Netton.

Ian Richard Netton melihat bahwa surah al-Kahf sengaja menampilkan narasi yang memaksa para pembaca untuk bisa mendudukkan keteraturan dan harmoni dalam narasi yang tidak beraturan. ${ }^{2}$ Hal ini misalnya digambarkan dalam kisah Nabi Hidhr dan Nabi Mūsa. Peristiwa-peristiwa yang melibatkan Nabi Hiidhr tentang perahu, anak kecil, dan tembok sebuah rumah terlihat sebagai suatu peristiwa kekacauan. Akan tetapi penjelasan akhir yang disampaikan

\footnotetext{
'Sahiron Syamsuddin, Hermeneutika dan Pengembangan Ulumul Qur'an (Yogyakarta: Pesantren Nawasea Press, 2017), 131.

2Ian Richard Netton, "Towards a Modern Tafsir of Surab al-Kabf: Structure and Semiotics," dalam Journal of Qur'anic Studies, Vol. 2, No.1 (2000), 68.
} 
oleh Nabi Hidhr atas tindakannya menunjukkan sebaliknya. Pola semacam ini juga terdapat dalam kisah-kisah lain dalam surah al-Kahf. Netton selanjutnya menganalisis surah ini dengan menggunakan pendekatan strukturalis dan semiotik untuk menemukan relasi-relasi yang terkait dalam setiap peristiwa sekaligus makna yang tersirat di dalamnya.

Sebenarnya, penafsiran Netton ini bukanlah satu-satunya. Mufasir modern Muslim kelahiran Mesir, Muḥammad al-Ghazāili, juga berusaha menyingkap relasi makna surah ini. Ia menyimpulkan bahwa di dalam surah al-Kahf terdapat sejarah umat manusia yang menceritakan persaksian mereka atas kebenaran tauhid. Oleh surah alKahf, sejarah ini dihadirkan melalui kisah-kisah yang beragam, mulai kisah pemuda ashāab al-kahf, kisah dua pemilik kebun yang sangat subur, kisah Nabi Müsa ketika bersama Nabi Ḥidhr, hingga kisah tentang Dhū al-Qarnayn. ${ }^{3}$ Pola penafsiran kedua tokoh ini menarik untuk disejajarkan. Menurut pandangan singkat penulis, keduanya memiliki perspektif yang sedikit berbeda meskipun pada sisi lain terdapat pandangan yang serupa.

\section{Ian Richard Netton dan Ketertarikannya Terhadap Kajian Alquran}

Ian Richard Netton adalah seorang profesor bidang Islamic Studies di University of Exeter, Inggris. Netton lahir di Singapura pada 3 Oktober 1948. ${ }^{4}$ Ia memperoleh gelar BA di bidang Bahasa Arab pada tahun 1972 di School of Oriental and African Studies (SOAS), London. Sementara gelar Ph.D diraih di University of Exeter pada tahun 1976 dalam bidang Filsafat Islam Abad Pertengahan. Karir akademiknya dimulai dari tahun 1977, dia diangkat sebagai pengajar Pemikiran dan Perdaban Islam di University of Exeter. Pada tahun 1995 dia mendapat gelar profesor Studi Arab pertama dari University of Leeds. Selain itu, dari tahun 1997-2002 dia menjabat sebagai Direktur Pusat Studi Abad Pertengahan di University of Leeds. Dia juga menjabat di berbagai komite nasional diantaranya Kepala Arts

\footnotetext{
${ }^{3}$ Muhammad al-Ghazāīi, Naḅw Tafsìr Mawdūi li Suwar al-Qur'an al-Karim (Beirut: Dār al-Shurūq, 2000), 230.

${ }^{4}$ http://edinburghuniversitypress.com/ian-richard-netton.html diakses pada tanggal 10 November 2017.
} 
and Humanities Research Council (AHRC) dan anggota dari kelompok penelitian Studi Islam. ${ }^{5}$

Secara umum fokus utama penelitian Netton berkisar dalam kajian Teologi dan Filsafat Islam, Sufisme, Studi Komparatif Teks dan Semiotik, Studi Komparatif Agama, dan Studi Islam. Dia telah menulis dan menjadi editor 23 buku, di antaranya Islam, Christianity and Tradition: A Comparative Exploration (Edinburgh University Press, 2006), Islam, Christianity and Mystical Journey: A Comparative Explanation (Edinburg University Press, 2011), dan Allah Transcendent Studies in the Structure and Semiotics of Islamic Philosophy, Theology, and Cosmology, Muslim Neoplatonist an Introduction to The Thought of the Brethren of Purity. ${ }^{6}$

Menarik untuk diperhatikan bahwa ketertarikan Netton pada bidang mistisisme dan filsafat Islam pada tahap selanjutnya mengantarkannya pada upaya pengkajian atas Alquran. Dalam karyanya Muslim Platonist, misalnya, dia telah banyak menghubungkan kajian mistisisme ikhwān al-Safā dengan kajian sastra Alquran, khususnya dikaitkan dengan penokohan para nabi. Pada karya ini sebenarnya Netton telah melakukan kajian semiotik terhadap kisahkisah para nabi ulu al-'azm dengan memaknai setiap tanda yang terjadi dan dibawa oleh para nabi. Tidak hanya itu, Netton juga mulai memaparkan metode intertekstualitasnya dengan mengaitkan kisahkisah para nabi yang terdapat pada Alquran dengan Bibel. Secara tegas dia menyatakan:

"cerita-cerita tentang para tetua dan para nabi dalam setting asli mereka adalah tuturan-tuturan yang berterus terang walaupun merupakan gabungan beberapa kisah yang berbeda, membawa pembaca ke depan dari kelahiran sampai meninggalnya sang pahlawan, dan menyajikan serangkaian peristiwa yang berurutan atau hampir berurutan. Tidak demikian halnya dengan Alquran. Di dalam Alquran para tokoh diperkenalkan untuk bertindak sebagai para pengkhotbah yang berhasil di zaman dahulu yang mengajarkan doktrin-doktrin yang disebarluaskan oleh Muhammad di zaman sekarang." 7

Pernyataan di atas pada tahap selanjutnya menarik Netton untuk semakin mendalami Alquran, khususnya yang berkaitan dengan kisah-

\footnotetext{
${ }^{5}$ http://socialsciences.exeter.ac.uk/iais/staff/netton/

${ }^{6}$ Ibid.

${ }^{7}$ Ian Richard Netton, Muslim Kebatinan, terj. Moch Musaffa Ihsan (Yogyakarta: Aditya Media, 1994), 98.
} 
kisah naratif dalam Alquran. Dalam berbagai kajiannya, Netton hampir tidak pernah abstain untuk menggunakan perspektif strukturalis dan semiotik sebagai pisau bedah analisisnya. Karya yang ditulis dalam bentuk artikel dengan judul "Toward a Modern Tafsir of Surah al-Kahf: Structure and Semiotics" merupakan salah satu ijtihad Netton sebagai bentuk konsistensinya. Dalam artikel ini Netton berupaya untuk memahami surah al-Kahf dengan menganalisis struktur surah yang dinilai sebagai surah yang kompleks, berisi berbagai kisah yang berbeda dan hanya dapat dipahami dengan kesabaran dan pengetahuan yang luas. ${ }^{8}$ Netton selanjutnya menggunakan perspektif semiotik untuk memahami surah ini. Pendekatan ini akan diuraikan secara lebih jelas dalam uraian berikutnya.

\section{Anatomi QS. Al-Kahf}

Al-Kahf adalah surah ke-68 yang turun kepada Nabi Muhammad setelah surah al-Ghāshiyah dan sebelum surah al-Shürā. ' Sebagian besar mufasir sepakat bahwa surah al-Kahf adalah seluruhnya makiyah. ${ }^{10}$ Tetapi tidak sedikit mufasir yang berpendapat bahwa surah yang terdiri dari 110 ayat ini tidak seluruhnya diturunkan di Makkah, sebelum hijrah. Pendapat ini sebagaimana yang ditulis oleh alZamakhshari bahwa surah al-Kahf ayat 38 dan ayat 83 sampai ayat 101 merupakan ayat yang turun setelah nabi hijrah. ${ }^{11}$ Terdapat riwayat lain yang menyebutkan ayat-ayat madaniyah dalam surah ini, akan tetapi menurut Ibn 'Āshür, pendapat yang lebih sahih adalah pendapat mayoritas mufasir, keseluruhan ayatnya adalah makiyah.

Secara historis, surah ini diturunkan ketika dakwah Nabi Muhammad mendapat penolakan dan tekanan dari kaum Quraish. Ketika itu, pemuka Quraish mengutus al-Naḍr b. al-Harith dan 'Uqbah b. Abi Muīt kepada para rabi Yahudi di Madinah. Mereka menyuruh utusan itu untuk bertanya tentang sifat-sifat Nabi

\footnotetext{
${ }^{8}$ Netton, "Towards a Modern Tafsir", 67.

${ }^{9}$ Muhammad al-Ṭăhir b. 'Āshūr, Tafsìr al-Taḅrìr wa al-Tanwīr, vol. 15 (Tunisia: Dār Sahnūn, 1997), 241.

${ }^{10}$ Muḥammad b. 'Ali b. Muhammad al-Shawkāni, Fatḥ al-Qadìr al-jämi' Bayn Fannay al-Riwāyah wa al-Dirāah min 'ilm al-Tafsir, vol. 3 (Beirut: Dār Ihyā' al-Turāth al-'Arabi: 1997), 268.

${ }^{11}$ Muḥammad b. 'Umar al-Zamakhsyāri, Tafsìr al-Kashshāaf, vol. 2 (Beirut: Dār al-Fikr, t.t), 271 .
} 
Muhammad dan mengabarkan tentang ucapan-ucapan beliau. Setelah tersampaikan, para rabi Yahudi itu menyuruh mereka untuk menanyakan tiga persoalan kepada Nabi Muhammad. Taruhannya adalah jika Muhammad dapat menjawab, maka beliau benar-benar Nabi yang diutus. Ketiga persoalan tersebut adalah: (1) pertanyaan tentang para pemuda yang pergi di masa lalu; (2) pertanyaan tentang seorang lelaki yang melakukan perjalanan ke seluruh belahan dunia timur dan barat; dan terakhir (3) pertanyaan tentang ruh. Setelah itu, utusan itu pun kembali ke Makkah dan kaum Quraish pun menanyakan tiga persoalan tersebut kepada Nabi Muhammad. Tanpa pikir Panjang, nabi mengatakan akan memberi jawaban atas pertanyaan tersebut. Perkataan nabi ini sama sekali tanpa disertai ucapan inshà' Allah. Lantas, beliau berdiam diri selama lima belas hari. Di waktu yang cukup panjang itu Allah tidak mengirimkan wahyu dan Jibril tidak mendatangi beliau sekalipun. Peristiwa ini kemudian disebarkan oleh kaum Quraish sehingga Nabi merasa sedih dan gelisah. Setelah itu Jibril pun datang membawakan surah al-Kahf sebagai obat kesedihan bagi nabi sekaligus untuk menjawab pertanyaan tentang pemuda, lelaki yang melakukan perjalanan, serta tentang ruh yang masuk dalam surah al-Isrāa. ${ }^{12}$

Selain berisi jawaban atas pertanyaan kaum Quraish di atas, surah al-Kahf ini secara lebih luas terdiri dari ayat-ayat tentang berbagai petunjuk bagi Nabi, janji dan ancaman, perumpamaan orang mukmin dan kafir, perumpamaan kehidupan dunia dan berbagai karunia Allah, tentang yaum al-ba'th dan al-hashr, peringatan terhadap para pendusta utusan Allah, pengahapusan politeisme, berbagai perumpamaan atas keluasan 'ilm Allah, serta diakhiri dengan penegasan bahwa Alquran adalah wahyu Allah yang diturunkan kepada rasul-Nya. ${ }^{13}$

\section{Penafsiran Ian Richard Netton Terhadap Surah al-Kahf}

Dalam memahami surah al-Kahf, Netton menggunakan langkah kerja yang digunakan dalam kritik sastra. Dalam kritik sastra, suatu karya sastra dianalisis, diurai unsur-unsur dan bagiannya, diselidiki, diperiksa, untuk kemudian disimpulkan nilainya. ${ }^{14}$ Pertama, Netton

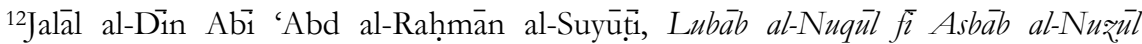
(Beirut: Dār al-Kutub al-'Ilmiyah, t.t), 129.

${ }^{13} \mathrm{Ibn}$ 'Āshūr, Al-Tahrìr wa al-Tanwìr, vol. 15, 241.

${ }^{14}$ Ali Imron, Semiotika, Kritik Sastra dan Semiotika al-Qur'an (Yogyakarta: Teras, 2011), 28.
} 
mendeskripsikan isi dari surah al-Kahf secara singkat dari kesimpulannya sendiri dan dari kesimpulan mufasir lain. Dengan langkah ini, Netton menyimpulkan bahwa yang ditekankan dalam surah al-Kahf adalah kekuatan yang teratur dan harmoni vis a vis kekuatan yang mengacaukan. Penekanan ini disebut oleh Netton dengan istilah topoi. ${ }^{15}$ Kedua, melakukan perbandingan intratekstual dengan surah Yüsuf dan perbandigan intertekstual dengan kisah dari berbagai teks dan tradisi lain. Ketiga, ketika masuk dalam analisis semiotik, Netton membagi surah dalam beberapa unit berdasarkan archetype (pola dasar). Keempat, dia menganalisis simbol-simbol dalam surah dengan mengungkap theologemes (unit-unit terdalam) dan fungsi archetype-nya. Terakhir, Netton menyimpulkan inti surah secara keseluruhan dari simbol-simbol yang telah dianalisis.

\section{Struktur dan Perbandingan Struktur Surah al-Kahf}

Berbeda dengan Yusuf Ali yang membagi surah al-Kahf dalam 12 bagian, Netton membaginya dalam delapan unit/aktan. Meskipun diakui bahwa pembagian ini dilakukan secara artifisial, akan tetapi pembagian ini berangkat dari pandangan bahwa setiap surah dalam Alquran adalah satu kesatuan. ${ }^{16}$ Pembagian ini dilakukan Netton dengan melihat topoi, archetype, dan theologemes yang terdapat di dalam surah al-Kahf: ${ }^{17}$ (1) pendahuluan, disampaikan dalam bentuk pujian dan peringatan: ayat 1-8; (2) kisah tentang penghuni gua (așhāb alkahf): ayat 9-26; (3) janji surga dan neraka I: ayat 27-31; (4) Perumpamaan pemilik kebun anggur: ayat 32-4; (5) kesementaraan hidup, kekuasaan, dan tanda-tanda kebesaran Allah: ayat 45-59; (6) kisah Nabi Mūsā dan Nabi Hiidhr: ayat 60-82; (7) Kisah Dhū alQarnayn, Ya'juj and Ma'juj: ayat 83-101; (8) janji surga dan neraka II dan perintah untuk Nabi Muhammad: ayat 12-110.

Selain mengurai bagian-bagian yang membentuk surah al-Kahf, Netton juga melakukan perbandingan struktur surah al-Kahf secara intratekstual dan intertekstual. Pertama, dalam analisis intratekstual, Netton membandingkannya dengan surah Yüsuf yang struktur dan kontennya sama sekali berbeda dengan surah al-Kahf. Surah Yüuf adalah narasi terpanjang dalam Alquran yang hanya mengisahkan satu

${ }^{15} \mathrm{Ibid}, 68$.

${ }^{16}$ Ibid, 69.

${ }^{17} \mathrm{Ibid}$. 
tokoh yaitu Nabi Yusuf. ${ }^{18}$ Menurut Netton, para ilmuan modern, seperti Yusuf Ali, Muhammad al-Ghazāili, Abdel Haleem, Rendsburg, Robinson, dan Mustansir Mir menilai sepakat atas keutuhan dan kelengkapan kisah Yusuf dalam QS. Yüsuf. Hal ini jelas sekali berbeda dengan kisah yang disebutkan dalam surah al-Kahf. Oleh karena adanya perbedaan yang jelas, Netton menilai bahwa tidak perlu eksplorasi yang luas untuk menjelaskan perbedaan keduanya. ${ }^{19}$ Sementara itu, QS. al-Kahf adalah surah yang secara artifisial terbagi ke dalam delapan bagian, di antaranya mengisahkan berbagai tema dan tokoh yaitu așhab al-kahf, Nabi Hidhr dan Nabi Mūāà, pemilik kebun anggur, Dhū al-Qarnayn dan Ya'juj and Ma'juj. ${ }^{20}$

Kedua, dalam analisis intertekstual, Netton membandingkan kisah dalam surah ini dengan teks atau narasi dari tradisi lain semisal kisah Seven Sleeper di Ephesus dari tradisi Kristen. ${ }^{21}$ Analisis interteks dilakukan oleh Netton di hampir seluruh kisah yang ada di dalam QS. al-Kahf. Analisis ini tidak dilakukan secara khusus oleh Netton, akan tetapi secara sekaligus dijelaskan dalam analisis semiotikya.

Kajian perbandingan teks ini berangkat dari pandangan bahwa suatu teks tidak lahir dari ruang kosong akan tetapi sebelum dan di sekitarnya terdapat teks-teks lain yang berkaitan dengan teks tersebut. Perbandingan teks dengan teks lain ini dipengaruhi oleh aliran strukturalisme Prancis yang dikembangkan oleh Julia Kristeva. Baginya, setiap teks merupakan penyerapan dan transformasi dari teks-teks lain. ${ }^{22}$ Informasi, kreatifitas, dan interpretasi yang diberikan terhadap teks lain yang terkait dapat menambah keluasan pandangan terhadap teks yang dikaji. Sehingga, menghadirkan teks-teks lain dalam suatu teks yang teliti dapat membantu proses pemahaman makna.

\footnotetext{
${ }^{18}$ Netton, "Towards a Modern Tafsir", 68. Mutawalli al-Sha'rawi juga menegaskan bahwa QS. Yüsuf adalah satu-satunya surah dalam Alquran yang mengisahkan satu tokoh secara lengkap dalam satu surah, berbeda dengan QS. al-Kahf yang mengisahkan berbagai tokoh dan peristiwa yang berbeda satu sama lain. Lihat M. Mutawalli al-Sha'rawi, Al-Qasas al-Qur'ani $\bar{f} \bar{i}$ Surat al-Kabf, terj. Tajuddin (Jakarta: Pustaka Panjimas, 1994), 4.

${ }^{19}$ Netton, "Towards a Modern Tafsir", 70.

${ }^{20} \mathrm{Ibid}, 69$.

${ }^{21}$ Ibid.

22Imron, Semiotika, 32.
} 


\section{Analisis Struktural-Semiotika terhadap QS. Al-Kahf}

Pada tahap ini, Netton mengidentifikasi archetype atau pola dasar karakter manusia yang terdapat di dalam QS. al-Kahf. Selanjutnya, dia mengidentifikasi theologemes yang ada di setiap archetypes. Istilah theologemes yang digunakan oleh Netton di sini dipengaruhi oleh LeviStrauss dan Roland Barthes yang menggunakan istilah seperti mytheme, gustheme dan vesteme. ${ }^{23}$ Strukturalisme Levi Strauss merupakan pengembangan dari konsep dasar strukturaslisme yang diperkenalkan oleh Ferdinand de Saussure dan dikembangkan menjadi antropologi struktural. Analisis strukturalisme Levi-Strauss menekankan pada pentingnya mengkaji struktur permukaan teks atau yang disebut dengan surface structure. Pengkajian ini sebagai titik awal untuk mengungkap struktur terdalam atau deep structure yang menjadi tujuan utama analisis ini. Dalam mengkaji struktur permukaan ini seseorang harus melihat bahwasanya sebuah kata tidak dapat berdiri sendiri, dia tidak meniliti perkata tetapi mengaitkan kata dengan kata lain, baik dengan kata sebelum atau sesudahnya dalam kalimat yang kemudian disebut sintagma, maupun hubungan kata tersebut dengan kata yang serumpun dengan arti yang sama atau biasa disebut paradigma.

Secara umum, terdapat beberapa prinsip dalam kajian strukturalisme atas teks; (1) prinsip imanensi, menekankan analisis pada struktur atau sistem dalam perspektif sinkronis maupun diakronis, (2) prinsip distingsi, analisis terhadap hubungan distingtif antar unsur dalam sistem yang mempunyai nilai berbeda-beda, (3) prinsip kesesuaian, mengkaji aturan-aturan yang menentukan kombinasi tiap-tiap elemen teks, (4) prinsip integrasi, struktur-struktur elementer harus diintegrasikan dalam totalitas sebuah sistem, (5) prinsip perubahan diakroni, (6) prinsip fungsional, mengkaji fungsi komunikasi dan fungsi-fungsi yang lainnya dari sistem. ${ }^{24}$

Untuk memenuhi prinsip-prinsip di atas, seorang strukturalis biasanya men-breakdown teks ke dalam "unit-unit naratif dasar" yang biasa disebut dengan "aktan-aktan". ${ }^{25}$ Dalam istilah Strauss, setiap teks dibagi dalam mythe-mythe yang kesemuanya dihubungkan oleh mytheme. Mythe adalah sesuatu yang mengisahkan sebuah cerita, sedangkan mytheme adalah unsur terdalam dalam konstruksi wacana

\footnotetext{
${ }^{23}$ Netton, "Towards a Modern Tafsir", 71.

${ }^{24}$ Ahmad Zaki Mubarok, Pendekatan Strukturalisme Linguistik. (Yogyakarta: Elsaq, 2007), 105.

${ }^{25}$ Syamsuddin, Hermeneutika dan Pengembangan, 67.
} 
mythe, di mana dia juga merupakan satuan-satuan yang bersifat oposisional. ${ }^{26}$ Levi-Strauss menggunakan istilah mytheme untuk menyebut unit terkecil atau satuan-satuan dalam mitos yang maknanya harus didapatkan terlebih dahulu sebelum menyimpulkan makna mitos secara keseluruhan. $^{27}$ Artinya, mytheme inilah yang menghubungkan satu mythe dengan mythe lainnya baik hubungan oposisional ataupun hubungan relasional. Dengan kata lain, mytheme memiliki peran yang cukup signifikan dalam konstruksi struktur dan kesatuan teks. Teori mytheme inilah yang merupakan kontribusi sekaligus ciri strukturalis Strauss yang kemudian menginspirasi Netton dalam teori theologeme-nya.

Meski demikian, Netton tampaknya kurang begitu puas dengan pendekatan strukturalisme yang dia adopsi dari Strauss. Hal ini terbukti dengan upayanya menggabungkan teori tersebut dengan semiotika. Meskipun Netton tidak memberikan alasan secara langsung signifikansi penggabungan dua pendekatan tersebut, akan tetapi hal ini dapat dipahami bahwa jika strukturalisme berupaya mengaitkan struktur-struktur atau mythe-mythe untuk kemudian menemukan struktur terdalam, maka dengan bantuan semiotika, kajian ini lebih memiliki wilayah yang lebih kaya dan mendalam.

Di tengah gagasannya mengenai pendekatan strukturalismesemiotik inilah teori theologemes dikemukakan oleh Netton. Ia mendefinisikannya sebagai unit dasar dari wacana teologis yang juga berfungsi sebagai tanda/simbol. ${ }^{28}$ Teori ini merupakan konstruksi wacana teologis yang berada di balik narasi teks dan berfungsi untuk menghubungkan satu kisah dengan kisah lainnya; relasional maupun oposisional. Dalam pengertian dan fungsi seperti ini sebenarnya tidak ada perbedaan sama sekali antara teori mytheme Strauss dengan theologeme Netton. Hanya saja jika objek mytheme adalah mitos-mitos dalam teks-teks "bukan kitab suci" maka objek theologemes adalah kitab suci, khususnya Alquran. Lebih lanjut, Netton menggunakan istilah archetypes untuk menyebut pola-pola dasar yang disimbolkan. Tampaknya istilah tersebut adalah pengganti dari istilah mythe dalam strukturalisme Strauss.

\footnotetext{
${ }^{26}$ Christhoper R. Badcook, Levi Strauss: Strukturalisme dan Teori Sosiologi, terj. Robby Habiba Abror (Yogyakarta: Pustaka Pelajar, 2008), 73-74.

${ }^{27}$ Heddy Shri Ahimsa Putra, Strukturalisme Levi-Strauss: Mitos dan Karya Sastra (Yogyakarta: Kepell Press, 2013), 86.

${ }^{28}$ Netton, "Towards a Modern Tafsir", 71. Lihat juga Ahimsa Putra, Strukturalisme Levi-Strauss, 86.
} 
Dari delapan unit pembagian terhadap QS. al-Kahf, Netton hanya memfokuskan pembahasaanya pada empat unit yaitu kisah tentang ashăb al-Kahf, kisah tentang pemilik kebun anggur, kisah Nabi Músā dan Nabi Hiidhr, dan kisah Dhū al-Qarnayn dan Ya'jüj and Ma'jü. Empat kisah ini kemudian dikelompokkan oleh Netton ke dalam lima archetypes:

\section{a. Sleeper}

Archetype sleeper diperankan oleh aṣhab al-Kabf. Dalam tradisi lain, tipe ini memiliki kesamaan cerita dengan kisah Seven Sleepers of Ephesus dalam tradisi Kristen. Selain itu, tipe ini juga paralel dengan dongeng Sleeping Beauty, dan mitos Rip van Winkle yang tertidur dalam waktu yang lama dan beberapa kisah lain. ${ }^{29}$ Kajian intertekstual ini terlihat kering karena Netton hanya menyebutkan kisah-kisah yang memiliki kemiripan akan tetapi dia tidak mengidentifikasi dan mengeksplorasi lebih lanjut informasi dari kisah-kisah tersebut.

Menurut Netton, theologeme dalam archetype ini adalah gua. Dalam sejarah Islam, gua menjadi lokus yang penting dalam dakwah Nabi. Ketika itu, gua menjadi tempat persembunyian Nabi dari kejaran orang-orang kafir Quraish. Sejarah awal Islam menunjukkan bahwa gua adalah simbol pewahyuan dan penjagaan. Dalam QS. al-Kahf, gua juga menjadi lokus pengamanan aṣ̆ab al-kahf dari kekejaman penguasa ketika itu, sehingga simbol gua dalam QS. al-Kahf adalah tempat keamanan dan perlindungan Tuhan. Adapun fungsi dari archetype sleeper ini adalah untuk menjelaskan kasih sayang Tuhan dan kekuasaanNya. ${ }^{30}$

\section{b. Proto-Muslim}

Archetype proto muslim diperankan oleh așhab al-Kahf dan pemilik kebun anggur yang beriman. Theologeme tipe ini adalah gua bagi ashab al-Kahf sebagaimana yang disebutkan di atas, dan kebun kurma bagi pemilik kebun kurma. Gua, selain sebagai tempat yang aman, dalam tipe ini merupakan simbol dari tempat berperannya nilai-nilai Islam dengan baik. Sementara itu, kebun kurma adalah simbol bagi tempat di mana monotheisme seharusnya diterapkan. Adapun fungsi dari archetype ini adalah untuk menunjukkan monotheisme, ketaatan dan penyerahan diri, perhatian Tuhan kepada orang beriman, petunjuk dan proteksi Tuhan kepada hamba-Nya, kemahatahuan Tuhan, kebenaran janji Tuhan, dan untuk menunjukkan bahwa segala

${ }^{29}$ Netton, "Towards a Modern Tafsir", 73.

${ }^{30} \mathrm{Ibid}$. 
tindakan bergantung pada kehendak Tuhan. Fungsi-fungsi ini didapatkan oleh Netton dari petunjuk-petunjuk yang secara eksplisit disebutkan oleh QS. al-Kahf. ${ }^{31}$

\section{c. Hero}

Archetype hero diperankan oleh Nabi Mūsā dan Dhū al-Qarnayn. Keduanya adalah archetype yang selalu melakukan penjelajahan dan selalu mendapatkan ujian demi ujian. Kisah dari tradisi lain semacam ini terdapat dalam mitos Jason and the Argonauts dari tradisi Yunani, Orpheus dari Yunani Latin, King Arthur dan the Knight of the Round Table dari mitos Inggris-Prancis. ${ }^{32}$ Menurut Netton, theologemes dari kisah Nabi Músā adalah tiga ujian yang dihadapi ketika bersama Nabi Hidhr. Dalam tradisi Kristen, theologemes ini seperti yang terdapat dalam tiga ujian Kristus di gurun. Tiga theologemes Nabi Mūsā tersebut adalah perahu yang menyimbolkan kemahatahuan Tuhan, anak kecil sebagai simbol dari keadilan dan kemahatahuan Tuhan, dan dinding rumah yang menyimbolkan Rahmat Tuhan. Sementara dalam kisah Dhū al-Qarnayn, dinding penghalang yang dibuat untuk melindungi kaum dari serangan Ya'juj dan Ma'juj adalah theologemes yang juga menyimbolkan Rahmat Tuhan. ${ }^{33}$

Fungsi dari archetype hero Mūsā dalam hal ini tidak dijelaskan oleh Netton. Pembahsan tentang Nabi Mūsā hanya berhenti sampai theologemes. Sementara archetype hero Dhū al-Qarnayn berfungsi untuk memperlihatkan penguasa yang adil yang dipilih oleh Tuhan dan untuk memperlihatkan penjagaan Tuhan. Fungsi yang terakhir ini sejalan dengan fungsi archetype sleeper dalam pembahasan sebelumnya. ${ }^{34}$

\section{d. Mystic}

Archetype ini diperankan oleh Nabi Hidhr yang memiliki paralelisme dengan figur lain seperti dalam kisah Tobias dan Archangel Rapael dalam tradisi Kristen. Theologemes dalam tipe ini adalah al-Tlm yang merupakan simbol dari adanya kemampuan memahami makna batin dan misteri dari suatu peristiwa dalam kehidupan. Kemampuan ini juga dimiliki oleh Nabi Yusuf yang diberi kemampuan oleh Tuhan untuk menafsirkan mimpi-mimpi. Fungsi dari archetype ini adalah untuk menafsirkan cara-cara Tuhan terhadap manusia yang terkadang terlihat sulit dan menyakitkan. Dalam hal ini

\footnotetext{
${ }^{31}$ Ibid., 73-74.

${ }^{32}$ Ibid.

${ }^{33}$ Ibid, 76.

${ }^{34}$ Ibid.
} 
penafsir sadar bahwa dia tidak bertindak atas kemauannya sendiri, akan tetapi menurut kemauan Tuhannya. ${ }^{35}$

\section{e. Anti-Hero}

Archetype anti-hero diperankan oleh pemilik kebun yang tidak beriman dan Yajuj and Ma'juj. Narasi tentang Ya'juj and Ma'juj ini memiliki kemiripan dengan dua raksasa dalam novel William Harrison, juga telah disimbolkan dalam bentuk tiga raksasa menara London yang bernama Og, Gog, dan Magog. Theologemes dari tipe ini sama dengan theologemes tipe lawannya yaitu kebun dan dinding pembatas. Adapun fungsi dari archetype pemilik kebun yang tidak beriman adalah peringatan akan bahaya politheism, sementara Yajuj and Ma'juj berfungsi untuk memberikan kesempatan kepada Tuhan untuk memperlihatkan kekuasaan-Nya melalui Dhū al-Qarnayn yang dapat mengalahkan Yajuj and Ma'juj. ${ }^{36}$

Setelah mengetahui theologemes yang terdapat pada kisah-kisah dalam Surah al-Kahf, Netton menyimpulkan bahwa terdapat hubungan dalam setiap rangkaian narasi yang diceritakan dalam surah tersebut. Menurut Netton, leitmotif (motif dasar) dalam QS. al-Kahf adalah harmoni versus kekacauan. Kekacauan-kekacauan yang terjadi dalam tiap kisah di atas dapat menjadi harmoni yang selalu melibatkan dimensi ketuhanan. Ketidakberdayaan așabab al-Kahf dikuatkan dengan penjagaan Tuhan selama tidur; 'kekacauan' yang dilakukan oleh Nabi Hidhr dapat diredam dengan penjelasannya sendiri; kekacauan dalam kebun kurma diatasi oleh aturan yang disampaikan oleh utusan Tuhan; dan kekacauan yang dilakukan oleh Ya'juj and Ma'juj dapat diatasi dengan penjagaan tuhan melalui Dhū al-Qarnayn. Kekacauan versus harmoni dalam QS. al-Kahf ini adalah salah satu simbol bagi kehidupan manusia yang dapat menjadi contoh di setiap masa, bahwa di setiap kekacauan, akan ada harmoni yang berasal dari kekuasaan Tuhan.

Perlu diakui, teori theologeme Netton telah sukses dalam memperluas dan memperdalam makna kisah dalam surah al-Kahf. Artinya, selain teori ini mampu menghubungkan narasi-narasi yang secara "lahiriah" tidak beraturan menjadi satu kesatuan struktur yang saling terkait satu sama lain, ternyata teori ini mampu menampilkan makna yang lebih dalam dari makna lahiriah teks tersebut. Ini tidak

${ }^{35} \mathrm{Ibid}$.

${ }^{36}$ Ibid., 78-79. 
terlepas dari kemampuan dan ketepatan Netton dalam mengeksplorasi problem narasi dalam QS. al-Kahf.

Dari sisi hermeneutik, terlebih jika dikaitkan dengan problem otonomisasi teks, theologeme memberikan ruang yang sepenuhnya terhadap penafsir untuk menentukan makna-makna yang dianggap konstekstual tanpa harus memperhatikan makna asal ataupun makna referensial sebuah teks. Kata "Gua" dalam konteks kisah surah alKahf misalnya, tidak lantas diartikan sesuai makna aslinya sebagai tempat yang terbuat secara alamiah oleh bebatuan, tetapi kata tersebut harus benar-benar otonom dari makna asalnya sehingga dapat diartikan sebagai pertolongan Tuhan melaui teori theologeme. Akibat dari otonomisasi teks seperti inilah maka aspek historis teks tidak selalu diperlukan. ${ }^{37}$ Historitas teks adalah kekayaan referensial yang tidak mesti menentukan sebuah makna. Dalam teori theologeme, makna ditentukan oleh hubungan relasional ataupun oposisional antara satu archetypes dengan archetypes lainnya. Hubungan inilah yang menentukan makna teks sebagaimana dapat dijelaskan melalui teori theologeme

\section{Distingsi Penafsiran Ian R. Netton dengan Muhammad al- Ghazāli}

QS. al-Kahf yang memuat berbagai cerita yang tidak saling berhubungan, dianalisis oleh Netton dengan pendekatan struktursemiotik. Ia mengurai surah ini dalam bagian-bagian sub tema agar dapat dilihat secara utuh. Pendekatan ini digunakan oleh Netton karena dia berangkat dari pandangan surah as a whole, setiap surah dalam Alquran adalah satu kesatuan. ${ }^{38}$ Pandangan ini seirama dengan pendapat Levi-Strauss yang menganggap teks sebagai satu kesatuan yang bermakna. Baginya, sebuah teks terdiri dari bagian-bagian yang membentuk cerita secara bersama-sama. Makna teks didapatkan dari keseluruhan makna bagian-bagiannya. Jika makna satu bagian berubah, maka makna keseluruhan teks akan bergeser. ${ }^{39}$ Langkah

\footnotetext{
${ }^{37}$ Mengenai otonomisasi teks ini, Paul Ricoeur menawarkan teori distansiasi. Secara ringkas, distansiasi memiliki empat bentuk dasar; pertama, distansi antara makna yang dimaksudkan dengan peristiwa pengucapan. Kedua, distansi antara ungkapan yang diinskripsikan dengan pengujar asli. Ketiga, distansi antara ungkapan yang diinskripsikan dengan audiens asli. Dan keempat, pembebasan teks dari rujukan pasti. Lihat: Paul Ricoeur, Hermeneutics and The Human Sciences, terj. Muhammad Syukri (Yogyakarta: Kreasi Wacana, 2006), 176.

${ }^{38}$ Netton, "Towards a Modern Tafsir", 69.

${ }^{39}$ Ahimsa Putra, Strukturalisme Levi-Strauss, 31-32.
} 
Netton untuk mengurai bagian-bagian dari QS. al-Kahf ini merupakan langkah awal memahami surah tersebut secara keseluruhan dan mendalam.

Pandangan ini sejalan dengan Muḥammad al-Ghazāili yang mendefinisikan Alquran sebagai kitab suci yang komprehensif, keseluruhan ayatnya adalah kesatuan yang saling mengikat, setiap surah di dalamnya juga memiliki kesatuan tema yang saling berhubungan, tidak saling bertentangan, saling menyatu, dan tidak terpisah-pisah. ${ }^{40}$ Aplikasi dari pendapatnya ini terlihat dalam karya tafsirnya, Naḥw Tafsir Mawdǖi li Suwar al-Qur'an al-Karim. Dalam kitab tersebut, al-Ghazāli selalu berusaha untuk menemukan pesan utama dari setiap surah. Sejalan dengan Netton, usaha dilakukan dengan menghubungkan pesan dari tema-tema kecil yang terdapat dalam satu surah. Namun, berbeda dengan Netton yang hanya menafsirkan empat tema kisah dalam QS. al-Kahf, al-Ghazāili menafsirkan dan mengaitkan seluruh bagian yang membentuk surah. Meski memang penjelasan ini hanya ditampilkan oleh al-Ghazāil secara global dalam bahasa yang sederhana.

Adapun poin-poin penafsiran al-Ghazāili terhadap QS. al-Kahf dapat dikelompokkan sebagai berikut: Pertama, ayat 1-6. al-Ghazāili menjelaskan bahwa Alquran adalah anugerah bagi manusia, sumber yang mempersatukan doktrin keesaan Tuhan. Begitu juga dengan alam semesta yang menyatakan bahwa Tuhan hanya satu, tidak memiliki anak, orang tua, dan yang selainnya adalah makhluk. Oleh karenanya manusia bertugas dan berkewajiban untuk mempelajari ayat-ayat-Nya, baik yang ada di alam maupun yang tertulis dalam Alquran. Orang yang percaya tauhid ini akan mendapat balasan yang baik, sebaliknya yang tidak percaya pun akan mendapat balasan. Nabi Muhammad sebagai pembawa risalah ini tidak tidak bertanggungjawab dan tidak perlu sedih dan kecewa terlalu dalam terhadap mereka yang menentang risalah ini. ${ }^{41}$

Kedua, ayat 9-26. Sebelum menjelaskan ayat ini, al-Ghazāili mengatakan bahwa di dalam surah ini terdapat contoh sejarah manusia yang bersaksi terhadap keesahan Tuhan. Pertama adalah aş̣ab al-kahf, para pemuda yang mempertahankan keyakinan tauhidnya dengan cara bersembunyi di gua. Bagi al-Ghazāili, kisah ini

${ }^{40}$ Amir Faishol Fath, The Unity of al-Qur'an, terj. Nasiruddin Abbas (Jakarta, Pustaka al-Kautsar, 2010), 436.

${ }^{41}$ Muḥammad al-Ghazāīi, Naḥı Tafsìr, 229-230. 
bertujuan memotivasi dalam menerima dan mempertahankan keyakinan tauhid..$^{42}$ Kesimpulan ini hampir sama dengan penafsiran Netton yang melihat fungsi kisah ini salah satunya sebagai tanda untuk menunjukkan monoteisme, meski Netton lebih menekankan fungsi manifestasi kasih sayang dan kekuasaan Tuhan. ${ }^{43}$

Ketiga, ayat 27-30 menjelaskan dua kelompok umat Nabi Muhammad yang mengimani dan menolak kisah ini. Mereka yang beriman akan tetap bersama Nabi, sementara yang mengingkari akan mendapat balasannya. ${ }^{44}$ Keempat, Sejalan dengan tema sebelumnya, ayat 32-44 menceritakan kisah kedua yang menegaskan keesaan Tuhan yaitu kisah dua pemilik kebun anggur, salah satunya beriman, dan lainnya adalah seorang kafir yang sombong. Pemilik kebun yang kedua ini kemudian mendapat hukuman setelah sebelumnya menolak nasihat tauhid yang disampaikan oleh pemilik kebun yang beriman. Bagi alGhazāil, ayat ini adalah peringatan kepada manusia, bahwa harta adalah anugerah Tuhan, bukan hasil mutlak manusia. Dari kisah ini, yang dimurkai Tuhan adalah kerendahan cara berpikir pemilik kebun yang menyekutukan Tuhan dengan (kesombongan) diri sendiri. ${ }^{45}$ Penekanan yang disampaikan oleh al-Ghazāi ini sama dengan hasil penafsiran Netton, bahwa fungsi dari kisah ini adalah sebagai simbol bagi tempat penerapan monoteisme. ${ }^{46}$ Kelima, ayat 45-59. Menurut alGhazāil, ayat ini adalah komentar Allah terhadap kisah sebelumnya, bahwa harta dan anak adalah hiasan dunia. Ia bisa menjadi alat jihad dan kemuliaan, tetapi jika manusia telah tenggelam dalam harta, maka dia akan menjadi senjata yang menghancurkan manusia. Pada hari akhir, manusia yang demikian ini tidak memiliki persiapan untuk bertemu Allah, karena ketika di dunia, dia tidak memperhitungkan akhiratnya. Terhadap ayat ini, al-Ghazāii lebih banyak memberikan kontekstualisasi terhadap problem manusia saat ini yang cenderung menjadikan dunia sebagai tujuan. ${ }^{47}$ Di sinilah salah satu letak perbedaan Netton dan al-Gazāli. Al-Gazāli lebih banyak mengaitkan penafsirannya dengan realitas manusia saat ini dari berbagai sisi, termasuk ibadah, sosial, ilmu pengetahuan, dan politik.

\footnotetext{
${ }^{42} \mathrm{Ibid}, 231$.

${ }^{43}$ Netton, "Towards a Modern Tafsir", 73.

${ }^{44}$ Ibid.

${ }^{45}$ Al-Ghazāili, Naḅw Tafsir, 233.

46Netton, "Towards a Modern Tafsir", 73-74.

${ }^{47}$ Al-Ghazāili, Naḅw Tafsìi, 235.
} 
Keenam, ayat 60-82. Ayat ini menceritakan kisah Nabi Müsā dan Nabi Hidhr yang digambarkan sebagai pahlawan dengan karakter memiliki kepercayaan diri dan kesabaran dalam menghadapi berbagai kesulitan. ${ }^{48}$ Penafsiran semacam ini juga dikemukakan oleh Netton, bahwa salah satu karakter pahlawan adalah selalu mendapat berbagai ujian dan rintangan. ${ }^{49}$ Di dunia ini ada hal-hal yang bersifat metafisik yang hanya diketahui oleh Allah, dan Ia berhak menentukan manusia yang dapat mengemban misinya. Perbuatan tidak wajar dan terlihat menyakitkan yang dilakukan oleh Nabi Hidhr adalah sebuah misi yang diberikan oleh Allah, bukan atas kehendaknya sendiri. Sehingga bagi al-Ghazāil, hikmah dari kisah ini adalah penyerahan diri terhadap kehendak Allah ketika hasil dari yang dilakukan tidak sesuai dengan harapan atau dugaan pribadi. ${ }^{50}$ Sejalan dengan ini, Netton juga menyimpulkan bahwa tindakan Hidhr bukan atas kehendaknya sendiri tetapi menurut kehendak Tuhan, sehingga menurut Netton, fungsi dari tokoh Nabi Hidhr adalah sebagai penafsir kehendak Tuhan terhadap manusia yang terkadang terlihat menyakitkan. ${ }^{51}$

Ketujuh, ayat 83-101. Bagian ini menceritakan Dhū al-Qarnayn, seorang pemimpin yang mendapatkan ilham, kekuasaan, dan ilmu pengetahuan. Ia digambarkan berhasil membantu dan mengatasi masalah yang dihadapi oleh berbagai kelompok, termasuk membentengi diri dari serangan kaum Ya'juj dan Ma'juj, generasi perusak yang tidak memiliki aturan syariat dan tuntunan wahyu yang akan menghancurkan akhir zaman. Bagi al-Ghazāli, inti dari kisah ini adalah usaha maksimal Dhū al-Qarnayn dalam menggunakan fasilitas dan sarana kekuatan yang diberikan oleh Allah. Ia meraih kejayaan kerajaan dengan iman, ilmu, hikmah, dan sikap kesadaran penghambaannya.52 Berbeda dengan al-Ghazāili yang lebih menekankan fokus kisah ini pada perjalanan kepemimpinan Dhū alQarnayn, Netton lebih melihat kisah ini sebagai simbol untuk memperlihatkan kualitas penjagaan Tuhan terhadap penguasa terpilihnya dari gangguan musuh. ${ }^{53}$

\footnotetext{
${ }^{48}$ Ibid.s, 236.

${ }^{49}$ Netton, "Towards a Modern Tafsir", 74.

${ }^{50}$ Al-Ghazāili, Naḅw Tafsir, 237.

${ }^{51}$ Netton, "Towards a Modern Tafsir", 76-77.

${ }^{52}$ Al-Ghazāìi, Naḥw Tafsìr, 238.

53Netton, "Towards a Modern Tafsir", 76.
} 
Kedelapan, ayat 102-110 merupakan penutup surah, yang menegaskan bahwa misi surah ini adalah untuk mengokohkan keyakinan tauhid dan menafikan sekutu Allah. Al-Ghazāili menemukan kaitan antara awal dan akhir surah, bahwa ayat di awal surah adalah perintah terhadap manusia untuk melaksanakan tugas dan kewajiban secara profesional sesuai dengan aturan Allah. Sementara akhir surah adalah penegasan bahwa Allah adalah satusatunya tujuan ibadah dan doa, satu-satunya tujuan dalam pelaksanaan tugas dan tanggungjawab. ${ }^{54}$ Penemuan al-Ghazāi ini menunjukkan bahwa inti penafsirannya berbeda dengan kesimpulan Netton, meskipun dalam beberapa sub-tema di atas terdapat kemiripan.

Meskipun kedua penafsir ini memiliki pendangan yang sama terhadap kesatuan dalam surah Alquran, akan tetapi pendekatan yang digunakan berbeda. al-Ghazāili menggunakan struktural-tematik sementara Netton menggunakan struktural-semiotik. Dengan mengaitkan pesan inti dari sub-sub tema surah, fokus yang ingin ditemukan oleh al-Ghazāil dalam setiap memahami surah Alquran adalah tema pokok dari suatu surah yang tidak keluar dari salah satu gagasannya, al-Mahawir al-Khamsah (lima tema-tema pokok); (1) keesaan Allah, (2) semesta sebagai datīl al-wnjüd (bukti keberadaan) Allah, (3) kisah-kisah Qur'ani, (4) kebangkitan dan pembalasan, serta (5) pendidikan dan pembentukan hukum. Kelima tema ini berada dalam satu tema besar, yaitu tauhid. ${ }^{55}$ Sebagaimana penafsirannya dalam QS. al-Kahf di atas, tema tauhid ditemukan oleh al-Ghazāi sebagai misi utama yang ingin disampaikan oleh surah tersebut.

Sementara itu, Netton dengan pendekatan semiotik berasumsi bahwa segala sesuatu adalah petunjuk yang memberi petunjuk (everything signifies) dan dia melihat bahwa Alquran telah mengisyaratkan hal ini dalam salah satu ayatnya, "Kami akan memperlihatkan tanda-tanda (kebesaran) kami di segenap penjuru dan pada diri mereka sendiri". ${ }^{56}$ Dengan ini maka bagi Netton, Alquran mengutamakan dan memperlihatkan dimensi eksoterik dan esoterik semiotik. ${ }^{57}$ Dua dimensi tersebut adalah fokus yang ingin didapatkan Netton dalam memahami QS. al-Kahf. Di dalam tulisannya, dia menyebutnya dengan istilah archetype dan theologeme. Dimensi eksoterik

${ }^{54}$ Al-Ghazāìi, Nahw Tafsìr, 239.

${ }^{55}$ Faishol Fath, The Unity, 439.

${ }^{56}$ QS. Fușșilat [41]: 53.

${ }^{57}$ Netton, "Towards a Modern Tafsir", 68. 
ditemukan oleh Netton dari pola-pola dasar karakter manusia (archetype) yang terdapat di dalam QS. al-Kahf, yaitu sleeper, protoMuslim, hero, mystic, dan anti-hero. Dalam setiap archetype tersebut terdapat tanda-tanda yang berdimensi ketuhanan/esoterik (theologemes). Tanda-tanda inilah yang ditafsirkan oleh Netton untuk kemudian secara keseluruhan disimpulkan bahwa kekuasaan Tuhan akan mampu menjadi harmoni bagi kekacauan yang dialami oleh berbagai tipe manusia tersebut.

\section{Penutup}

Pendekatan Struktural-semiotik yang dilakukan oleh Ian Richard Netton ini merupakan salah satu upaya alternatif untuk memahami pesan-pesan Alquran yang disampaikan melalui kisah. Pendekatan Netton ini diantaranya dipengaruhi oleh pendekatan Levi-Strauss terhadap mitos-mitos. Dengan kajian ini, pesan-pesan yang disampaikan oleh Alquran dapat digali secara lebih mendalam yang mungkin tidak dapat ditemukan oleh pendekatan yang bahasa yang biasa digunakan oleh para mufassir. Dalam semiotik, kajian yang telah melibatkan kajian intertekstual adalah upaya untuk menemukan makna tingkat kedua.

Selain oleh Netton, pendekatan struktural terhadap Alquran juga dilakukan oleh penafsir Muslim, Muhammad al-Ghazāli. Namun dalam hal ini al-Ghazāli tidak menggunakan pendekatan strukturalsemiotik seperti halnya Netton, akan tetapi menggunakan pendekatan struktural-tematik. Dengan pendekatan ini, al-Ghazāi $\bar{i}$ berupaya memahami surah-surah di dalam Alquran dalam satu kesatuan tema yang disimpulkan dari sub-sub tema yang membentuknya. Ia mencoba memahami satu surah Alquran secara utuh, dari awal hingga akhir. Ini berbeda dengan Netton yang hanya menafsirkan empat tema kisah dalam QS. al-Kahf. Namun di sisi lain, penafsiran Netton ini terlihat lebih mendalam.

Akan tetapi, kajian yang dilakukan oleh Netton ini melepaskan diri dari asbāb al-nu₹ūl (konteks yang melingkupi turunnya ayat). Sehingga, kajian ini terkesan sebagai kajian yang subjektif. Berbeda dengan al-Ghazāili, meski penafsirannya ditulis secara global, tetapi dia berusaha berpikir objektif dengan melibatkan konteks ayat, mengaitkannya dengan ayat lain dan hadis setema, serta melakukan kontekstualisasi ayat dengan problem manusia saat ini. Meski pendekatan dan hasil kedua penafsiran ini berbeda, apa yang 
dilakukan oleh Netton dan al-Ghazāli ini dapat disebut sebagai upaya hermeneutis. Keduanya berusaha menggali makna terdalam dari satu kesatuan surah Alquran.

\section{Daftar Pustaka}

'Āshūr (Ibn), Muhammad al-Ṭāhir. Tafsìr al-Taḅrì wa al-Tanwìr. Tunisia: Dār Sahnūn, 1997.

Badcook, Christhoper R. Levi Strauss; Strukturalisme dan Teori Sosiologi, terj. Robby Habiba Abror. Yogyakarta: Pustaka Pelajar, 2008.

Fath, Amir Faishol. The Unity of Alquran, terj. Nasiruddin Abbas. Jakarta, Pustaka al-Kautsar, 2010.

Ghazāili (al), Muhammad. Naḥw Tafsì Mawdūi ì li Suwar al-Qur'än al-Karim. Beirut: Dār al-Shurūq, 2000.

Imron, Ali. Semiotika, Kritik Sastra dan Semiotika Alquran. Yogyakarta: Teras, 2011.

Mubarok, Ahmad Zaki. Pendekatan Strukturalisme Linguistik. Yogyakarta: Elsaq, 2007.

Netton, Ian Richard. "Towards a Modern Tafsir of Surab al-Kabf: Structure and Semiotics", dalam Journal of Qur'anic Studies, Vol. 2, No.1, 2000.

Muslim Kebatinan, terj. Moch Musaffa Ihsan. Yogyakarta: Aditya Media, 1994.

Palmer, Richard E. Hermeneutics Interpretation Theory in Schleirmacher, Dhilthey, Heidegger, and Gadamer. Terj. Mansur Hery dan Damanhuri Muhammed. Yogyakarta: Pustaka Pelajar, 2005.

Putra, Heddy Shri Ahimsa. Strukturalisme Levi-Strauss: Mitos dan Karya Sastra. Yogyakarta: Kepell Press, 2013.

Ricoeur, Paul. Hermeneutics and The Human Sciences, terj. Muhammad Syukri. Yogyakarta: Kreasi Wacana, 2006.

Sha'rawi (al), M. Mutawalli. Al-Qasas al-Qur'ani fi Sürat al-Kahf, terj. Tajuddin. Jakarta: Pustaka Panjimas, 1994.

Shawkānì (al), Muḥammad b. 'Aबii b. Muḥammad. Fatḥ al-Qadìr al-Jāmi" Bayn Fannay al-Riwayah wa al-Dirayah min 'ilm al-Tafsir. Beirut: Dār Inyāa' al-Turāth al-'Arabi: 1997.

Suyự̦i (al), Jalāl al-Dìn Abi 'Abd al-Raḥmān. Lubāb al-Nuqūl fí Asbāb alNuฉūl. Beirut: Dār al-Kutub al-'Ilmìyah, t.t.

Syamsuddin, Sahiron. Hermeneutika dan Pengembangan Ulumul Qur'an. Yogyakarta: Pesantren Nawasea Press, 2017.

Zamakhsyāri (al), Muhammad b. 'Umar. Tafsìr al-Kashshäf. Beirut: Dār alFikr, t.t. 